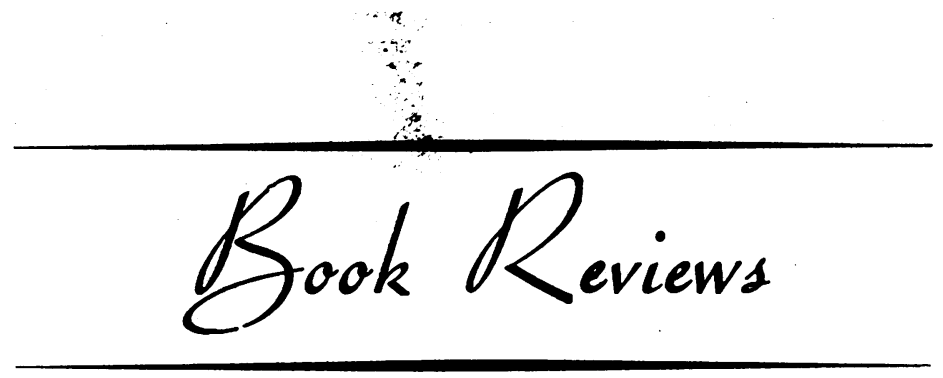

\section{A Catalogue of THE PORTRAits AND OTHER PAINTINGS, DRAWINGS AND SCULPTURE IN THE ROYAL COLLEGE OF SURGEONS OF ENGLAND}

By William LeFanu, Librarian of the College. Pp. xii + 119. Illustrated. E. \& S. Livingstone Ltd., Edinburgh and London. 1960. 30s.

This work, completed by the accomplished and ever-helpful librarian of the Royal College of Surgeons and betraying the meticulous care and the love of the College collections that everyone would expect of its author, is at once the story of the College and many of the distinguished surgeons associated with it, and the history of painting and sculpture during the 18 th, 19 th and 20 th centuries and even earlier. This is the third catalogue of the portraits and busts of the College and contains many accessions since the publication of Sir Frederic Hallett's revised catalogue of 1930 .

The publication of this complete list of the College's art treasures has been facilitated by a gift from Mr. McNeill Lore, a past member of Council, in memory of his son, Michael, and Mr. LeFanu has also been fortunate in the encouragement and advice tendered him by Sir Geoffrey Keynes, the distinguished littérateur and art critic.

The work has been produced with all the skill and perfection that habitually associate themselves with the name of the publishers. The author and his publishers have set up for themselves monumentum aere perennius.

\section{PRACTICAL PROCEDURES IN CLINICAL MEDICINE}

By R. I. S. Bayliss, M.D., F.R.C.P. Pp. xvi +462. Illustrated. London: J. \& A. Churchill Ltd. I $960.42 s$.

This well established favourite is now in its third edition. It provides succinct instruction in the techniques and interpretation of clinical procedures carried out in the medical ward and outpatient department. There are descriptions of the simpler laboratory investigations which housemen may be called upon to perform while the laboratory is closed. The opportunity of preparing a new edition has been put to good use by including new techniques (e.g. serum glutamic oxaloacetic transaminase tests) and pruning the dead wood, so that the total length of the book is not increased. The book remains an essential vade mecum for the house physician.

\section{MODERN TREATMENT YEARBOOK, I960}

Edited by Sir Cecil Wakeley, Bart., K.B.E., C.B., F.R.C.S. Pp. xviii +3 ro. Illustrated. London: Baillière, Tindall and Cox. 1960. 33s.

This is the twenty-sixth annual volume designed to provide brief practical information for the general practitioner. It succeeds admirably in keeping essentials to the fore and helping the practitioner to deal correctly with a large number of topical conditions. The general practitioner is in a particularly difficult position with regard to keeping up-to-date on the whole front of medicine, surgery, gynaecology and all branches as so many articles are too specialized to be of much value to him. This book is an exception. It contains thirtytwo short articles, each by a separate author, with a definite bias to surgical subjects. The majority are written in an easy crisp style and provide only few references or none at all. It is certain to stimulate higher standards in general practice.

\section{ANTIBIOTICS ANNUAL, r959-60 \\ Annual Symposia on Antibiotics}

Edited by $H$. Welch and F. Marti-Ibanez. Pp. $x x+1,034$. New York: Antibiotics Inc. Distributed by Interscience Publishers Ltd. r960. £5 5s.

This is the proceedings of the Seventh Annual Symposium on Antibiotics which was held in Washington, D.C., in November 1959, and consists of 150 papers on various aspects of the latest developments in antibiotics.

The book contains a description of several newily. isolated antibiotics of which colistin (of Japanese origin) and rifomycin seem to be the most promising. Of more immediate interest to British readers is an evaluation of demethylchlortetracycline and its uses. The greatly increased incidence of the American gonococcus being insensitive to the 'shot of penicillin' is reflected by the appearance of seven papers devoted to newer therapeutic regimens for its eradication. Also described is experience with some of the synthetic penicillins and the advent of a potent new anti-fungal agent, griseo- 